\title{
ONLINE DISTANCE LEARNING FOR TRANSLATION SUBJECTS: TERTIARY LEVEL INSTRUCTORS' AND STUDENTS' PERCEPTIONS IN SAUDI ARABIA
}

\author{
Dr. Khaled ALDOSSARY \\ ORCID: 0000-0002-4917-3258 \\ Department of English Language and Translation \\ King Saud University \\ Riyadh, SAUDI ARABIA
}

Received: 31/08/2020 Accepted: 09/11/2020

\begin{abstract}
Amid the vast spread of the novel coronavirus COVID-19, educational institutions worldwide have shifted to eLearning platforms. This abrupt shift from traditional face-to-face teaching to virtual online classes has brought about some challenges. The central objective of this study is to explore university instructors' and students' perceptions of utilizing eLearning platforms for teaching and learning translation subjects. The study sample consisted of mixed-gender faculty members $(\mathrm{n}=22)$ and undergraduate students ( $\mathrm{n}$ = 133) from the Department of English Language and Translation (DELT) in the College of Languages and Translation (COLT) at King Saud University (KSU). A quantitative research design was used. Two separate five-point Likert scale questionnaires were distributed to instructors and students, respectively. The findings revealed that neither instructors' nor students' perceptions of eLearning differed, and a number of benefits were reported. The paper concludes with the limitations and implications of the findings as well as suggestions for future research.
\end{abstract}

Keywords: eLearning translation, instructors' perceptions, students' perceptions, virtual classrooms.

\section{INTRODUCTION}

Information technology (IT) has become a significant tool within modern educational processes as internet use is now widely adopted in educational institutions for learning purposes. IT has therefore influenced the evolution of eLearning in education, and higher education in particular (Northcote \& Gosselin, 2016). This evolution has led to the establishment of modern educational environments such as distance learning, e-learning, and blended learning across higher education institutions in Saudi Arabia.

In the literature, there is no clear and explicit definition of eLearning, and the definitions that exist are sometimes contradictory (Rice \& Gregor, 2016). The term "eLearning" is often used interchangeably with other terms such as "distance learning" and "online learning." In the field of teaching and learning languages, eLearning refers to instances where learning a language occurs fully online, with no face-to-face interaction in the context of the formal language course (Hockly, 2015). It is therefore seen as an interactive process within which students interact with teachers either synchronously (i.e., they are online simultaneously) or asynchronously (i.e., they do not have to be online at the same time) (Tunmibi, Aregbesola, Adejobi, \& Ibrahim, 2015). This study uses the terms "eLearning" and "online distance learning" (ODL) interchangeably to refer to the process of distanced learning over the internet in an academic realm.

In Saudi Arabian higher education, eLearning has grown significantly over the past two decades, particularly in higher education, and this has led public universities to invest heavily in its development. King Saud University (KSU) was one of the earliest universities to implement online learning in Saudi Arabia, and over the years, it has made efforts to implement eLearning in all its colleges. This practice has been achieved through creating eLearning units across all colleges to establish an appropriate e-environment. The role of these units, supported by the Deanship of eLearning and Distance Education, extends to training faculty members on online teaching in general and the use of different eLearning platforms specifically, such as 
the Learning Management System (LMS) (Aljaber, 2018). Through these units, KSU has continuously worked to improve the quality and standards of eLearning and successfully automated its eLearning system. Regardless, the sudden shift from traditional face-to-face teaching to a $100 \%$ online mode may bring about some challenges.

The vast spread of the novel coronavirus COVID-19 has led to great changes in education systems around the world, and Saudi Arabia is no exception. The most prominent change is the call for a rapid transition from face-to-face classes to virtual ones, i.e., online learning. Although several studies have looked into students' perceptions of ODL in Saudi Arabia (e.g., Zabadi \& Alawi, 2016; Alfehaid, 2019; Alwahoub, Azmi, \& Jomaa, 2020), the significance of the current research lies in its specific exploration of both instructors' and students' perceptions of the eLearning of English-Arabic Translation subjects at KSU. Perceptions are a key factor that shape how instructors and students approach tasks, and hence influence the entire learning process (Getie, 2020). Thus, knowledge about students' attitudes and perceptions will likely help educational institutions and faculty members understand current practices as well as promote and apply suitable forms of online learning to meet student needs. To achieve this, a large and growing body of literature has explored teachers and students' perceptions of eLearning and reported positive results.

It is worth noting that prior to the COVID-19 pandemic, all translation subjects at KSU were taught faceto-face in the Department of English Languages and Translation (DELT). Teaching translation subjects is different from teaching other English subjects, as specialized translation laboratories and interpreting tools are integral resources. Given the nature of these subjects, it is useful to explore instructors and students' perceptions of the efficacy of virtual environments for translation coursework. This study therefore attempts to answer the following questions:

a. What are instructors' perceptions of using eLearning for teaching translation courses?

b. What are students' perceptions of using eLearning for studying translation courses?

c. Is there a significant difference between the responses of instructors and students?

\section{LITERATURE REVIEW}

In recent years, special emphasis has been given to eLearning in educational institutions as research has reported several benefits. These benefits include the elimination of physical and temporal limitations (e.g., Hew, Qiao, \& Tang, 2018), ease of content access and schedule flexibility (e.g., Zabadi \& Alawi, 2016; Junior et al., 2019), and cost-effectiveness (Gülbahar, 2012). Other studies have shown that eLearning is effective for student gains and performance (e.g., Geta \& Olango, 2016; Isti'anah, 2017; Cabi \& Kalelioglu, 2019). However, in order to attain the best outcomes of eLearning, students must be actively involved in the learning process (Keengwe, 2015) - a concept often referred to as active learning (Kishore \& Alekhya, 2018). Bonwell (1991) asserted that in active learning, students participate in the process, and they only participate when they do something and think about it.

A critical factor that can influence students' participation, such as their appropriate and active engagement in the learning process, is their attitude towards online learning. It is necessary, therefore, to consider discrepancies in teachers' and students' perceptions when implementing eLearning activities to avoid any resistance that may bring about disinclination or ineffectiveness (Alfehaid, 2019). According to Rhema and Miliszewska (2014), students' perceptions of eLearning are key determinants of future eLearning initiatives, and positive perceptions of eLearning are critical to students' readiness and inclusion in online learning.

Some studies have compared the effectiveness of virtual learning and traditional classroom learning. A longitudinal study by Banafshi et al. (2020) compared the impact of virtual and face-to-face learning on 60 EFL Iranian learners' vocabulary acquisition. Following a pre-/post-test design, participants were randomly divided into control and experimental groups. The control group received face-to-face instruction in the classroom, whereas the experimental group used the Telegram application. The post-test findings showed that although both groups improved, those who received online instruction showed significantly better improvement $(M=26.60)$ than the control group $(M=20.80)$. The researchers concluded that online classes were more effective. Other studies have extended this investigation by examining the effect of learning modes on the nature of interaction. For example, Tan et al. (2010) examined six pairs of beginner learners 
who collaboratively completed two versions of seven writing tasks over 10 weeks. One set of tasks was completed in a face-to-face mode in a classroom, and the other was completed outside class time using an online platform. The study found collaborative patterns only in the group that received eLearning. The researchers concluded that computer-mediated learning was a useful L2 pedagogical tool and could promote higher engagement.

Several studies have attempted to elicit students' perceptions of face-to-face and computer-mediated learning. For instance, Nazara's (2016) mixed-methods study explored the perceptions of 42 EFL Indonesian students. Their attitudes were generally neutral toward face-to-face instruction but positive toward blended learning. The participants reported that blended learning was not only effective but also contributed to their critical thinking and self-learning. A quasi-experimental study by Suwantarathip and Wichadee (2014) compared the writing ability of students who collaborated on writing assignments using Google Docs with those working in groups in a face-to-face classroom and elicited their perceptions. The Google Docs group showed better performance than the face-to-face group as well as strong positive attitudes toward engaging in more online learning. A recent study by Al-Hattami (2020) explored instructors and students' perceptions of the transition from face-to-face to online learning. Online learning was perceived as effective because it reportedly helped instructors provide prompt and direct feedback, encouraged students to participate, and enhanced students' performance and achievements. Both instructors and students indicated they were willing to use eLearning in the future. Sanad (2020) conducted a study involving instructors and students from various Egyptian private and governmental universities to elicit their perceptions of eLearning implementation. The results indicated positive attitudes of instructors and students towards eLearning. There was a consensus among the participants that eLearning was easy to use, enhanced students' critical thinking, and contributed to their learning.

Studies in Saudi Arabia have also provided positive results from eLearning. For example, Alzahrani (2017) found a positive effect of blended learning on Saudi students' achievement and reported students' general satisfaction with eLearning. Sajid et al. (2016) likewise reported that EFL students were satisfied with blended learning as a novel, relevant, and effective approach and even agreed that it aided with exam preparation. The students also demonstrated a preference for more online lectures. Aljuda (2017) conducted a quantitative study targeting a large sample of male and female students $(\mathrm{N}=500)$ at a Saudi university. All students, regardless of gender, reported positive perceptions of eLearning. Aljuda concluded that proper training, guidelines, and instructions were key factors that influenced student attitudes.

In a more comprehensive study, Alfehaid (2019) used both qualitative and quantitative methods to explore instructors and students' perceived influence of online English learning activities on academic achievement at a Saudi university. The findings showed that instructors and students perceived online activities to have a positive effect on academic performance. In addition, interviews with students revealed that online activities enabled them to practice the language independently outside the classroom. Alodail (2016) explored male and female instructors' attitudes towards eLearning at a university in Saudi Arabia. The findings revealed that all participants maintained a positive attitude towards eLearning, but the female group had positive attitudes higher than males. The researcher concluded that perceived computer competence was a key factor that influenced the participants perceptions. A recent mixed-method study by Anas (2020) showed students' positive attitudes towards eLearning as an interactive environment that enabled them to share information and collaborate in resolving learning challenges. The perceived usefulness of online learning has similarly been acknowledged at different levels of education beyond the university. As one example, Alwahoub et al. (2020) explored perceptions of eLearning in Saudi primary schools. The quantitative analysis showed positive perceptions of eLearning from students and teachers. Furthermore, teachers perceived eLearning as effective and said it promoted students' overall knowledge, while students agreed that eLearning helped them improve their knowledge and said it provided better opportunities for more collaboration with peers and teachers.

Although these studies explored teachers' and students' perceptions of eLearning at the tertiary level, the majority focused on the teaching and learning of English as a foreign language. Research investigating the perceptions of teaching and learning translation subjects is obviously scarce. In contrast to the above studies, this study investigates university instructors' and students' experiences of using online platforms to teach and learn English-Arabic translation subjects and to what extent the two groups perceive eLearning as having an influence on student achievement in translation subjects. 


\section{METHOD}

\section{Participants}

The population of this study, selected randomly, consisted of instructors and undergraduate students in KSU's DELT. The instructors were male and female faculty members of COLT who had taught translation subjects online (i.e., written and oral translation subjects). Their academic ranks varied from teaching assistant to associate professor, and their age range was 21-61 years. There were 133 student participants from different academic levels (levels 6 to 10, where 10 is the final level). Their ages ranged from 19-25 years. Table 1 summarizes the participants' demographic characteristics.

By the end of the second semester of the 2019-2020 academic year, all participants had been using online learning for translation subjects for over two months due to the university closure following the COVID-19 outbreak. The data collection was anonymous and no personal information was collected from the respondents. The respondents were also informed that their responses would remain confidential and would be used for research purposes only.

Table 1. Demographic information of the participants

\begin{tabular}{cccc}
\hline & Gender & Frequency & Percentage \\
\cline { 2 - 4 } Faculty members & Male & 9 & 40.9 \\
& Female & 13 & 59.1 \\
& Total & 22 & 100 \\
\hline \multirow{3}{*}{ Students } & Male & 21 & 15.8 \\
& Female & 112 & 84.2 \\
& Total & 133 & 100 \\
\hline
\end{tabular}

\section{Design}

For the purpose of answering the research questions, a quantitative approach was employed. Two questionnaires were developed by the researcher based on the related literature: one for the instructors and one for the students. The instructor and student questionnaires were given to seven experts (four Curriculum and Instruction and three EFL university professors) for validation. The content and construct validity of the instruments were examined and modified following the experts' suggestions and comments.

\section{Instructor Questionnaire}

The instructor questionnaire consisted of 21 items divided into two main sections: 1) demographic information (six items) and 2) perceptions of teaching translation courses online (15 items). The item responses used a five-point Likert scale $(5=$ strongly agree, $4=$ agree, $3=$ neutral, $2=$ disagree, and $1=$ strongly disagree). All items in the instructor questionnaire were checked for reliability, and the results showed a good internal consistency where Cronbach's alpha was 0.84 .

\section{Student Questionnaire}

The student questionnaire was similar to the instructor questionnaire in that it used the same five-point Likert scale and the same number of items, but with slightly different wording adapted to fit the student experience. The questionnaire was piloted with nineteen students to establish its reliability. Cronbach's alpha was 0.82 , thereby indicating a high internal consistency of items. The means of both the instructor and student questionnaires were classified as follows: "strongly disagree" from 1.00 and 1.80, "disagree" from 1.81 to 2.60 , "neutral" from 2.61 to 3.40 , "agree" from 3.41 to 4.20 , and "strongly agree" from 4.21 to 5.00 . 


\section{Data Collection and Statistical Analysis}

Web-based versions of the instructor and student questionnaires were distributed to all participants at the end of the second semester of the 2019-2020 academic year. The instructor questionnaire was sent to 29 instructors, and 22 of them responded. The student questionnaire was circulated to 154 students at different levels (levels 6 to 10), and 133 students completed it. Once the questionnaires were collected, the data were processed and analyzed using the Statistical Package for Social Sciences (SPSS) to obtain the means and standard deviations for each item. Then, the outcomes of the two questionnaires were compared via an independent samples t-test.

\section{FINDINGS}

This study aims at exploring EFL instructors' and students' perceptions of using online learning for translation subjects. It also attempts to investigate whether there are any differences between the participants' perceptions. This section presents the findings based on the three research questions and provides explanations for the findings.

\section{Instructors' Perceptions of Online Distance Learning}

The first question of this study concerns instructors' perceptions of using eLearning for teaching translation subjects. Table 2 presents the means and standard deviations of each item in the instructor questionnaire.

Table 2. Means and standard deviations of the instructor questionnaire items

\begin{tabular}{|c|c|c|c|c|}
\hline Item No. & Rank & Item & Mean & $\begin{array}{l}\text { Standard } \\
\text { Deviation }\end{array}$ \\
\hline 8 & 1 & $\begin{array}{l}\text { The methods of presentation and content delivery are appropriate for } \\
\text { learning. }\end{array}$ & 3.68 & 0.78 \\
\hline 6 & 2 & $\begin{array}{l}\text { The tasks and assignments are easily understood and facilitate } \\
\text { learning. }\end{array}$ & 3.64 & 0.727 \\
\hline 13 & 3 & $\begin{array}{l}\text { There is a lack of social interaction between the instructor and } \\
\text { students, and among the students themselves. }\end{array}$ & 3.59 & 0.959 \\
\hline 9 & 4 & $\begin{array}{l}\text { It is easy for students to understand the content when studying } \\
\text { online. }\end{array}$ & 3.59 & 1.182 \\
\hline 12 & 5 & $\begin{array}{l}\text { There are opportunities for collaborative work in ODL (i.e., completing } \\
\text { tasks/assignments in cooperation with classmates). }\end{array}$ & 3.50 & 0.74 \\
\hline 7 & 6 & $\begin{array}{l}\text { Feedback on assignments and examinations is timely (i.e., feedback is } \\
\text { sent back to students quickly). }\end{array}$ & 3.46 & 0.912 \\
\hline 1 & 7 & ODL is useful for translation courses. & 3.32 & 0.945 \\
\hline 2 & 8 & ODL enhances students' learning autonomy (i.e., self-learning). & 3.14 & 0.889 \\
\hline 4 & 9 & $\begin{array}{l}\text { ODL does not increase students' motivation for learning. (negative } \\
\text { statement) }\end{array}$ & 3.14 & 1.125 \\
\hline 14 & 10 & $\begin{array}{l}\text { It is difficult to contribute to class discussions in an ODL translation } \\
\text { course. }\end{array}$ & 3.14 & 1.207 \\
\hline 10 & 11 & Students cannot be contacted easily. (negative statement) & 3.05 & 1.214 \\
\hline 11 & 12 & Responding to students' inquiries takes time. & 2.91 & 1.269 \\
\hline 5 & 13 & ODL contributes to students' learning achievements. & 2.77 & 0.813 \\
\hline 15 & 14 & I would like to have more translation courses taught online. & 2.5 & 1.263 \\
\hline 3 & 15 & $\begin{array}{l}\text { I prefer ODL translation courses to the traditional ones (i.e., face-to- } \\
\text { face teaching). }\end{array}$ & 2.32 & 0.995 \\
\hline \multicolumn{3}{|r|}{ Overall mean } & 3.18 & 0.233 \\
\hline
\end{tabular}


The overall mean scores shown in Table 2 indicate neutral perceptions of the instructors towards using eLearning for teaching translation subjects $(M=3.18)$. Table 2 also shows that the mean scores ranged from 2.32 and 3.68, with standard deviations from 0.99 to 1.26 . Items $8,6,13,9,12$, and 7 had mean scores ranging from 3.46 to 3.68. These items fell within the "agree" category, which accounted for $40.01 \%$ of all the instructor questionnaire items. Table 2 also shows that Items 1, 2, 4, 14, 10, 11, and 5 had mean scores ranging from 2.77 to 3.32 . These items fell within the "neutral" category, which constituted $46.66 \%$ of the total items. Items 15 and 3 had the least mean scores ranging from 2.32 and 2.50, respectively. These items fell within the "disagree" category, which comprised $13.33 \%$ of all items.

These findings show that the instructors agreed that the online methods of presentation and content delivery were appropriate for learning (Item $8, M=3.68$ ) and that the students understood the tasks and assignments easily, which helped facilitate their learning (Item $6, \mathrm{M}=3.64$ ). They also agreed that there was a lack of social interaction between them and the students, and among the students themselves (Item 13, M = 3.59) but indicated that this did not impact the students' understanding of the course contents (Item 9, M = 3.59) nor their opportunities for engaging in collaborative work (Item 12, M =3.50). The instructors responded that timely feedback was given on student assignments and examinations (Item 7, M = 3.46).

However, they were undecided about whether ODL was generally useful for translation subjects (Item 1, M = 3.32). The instructors were also neutral about whether ODL could improve students' learning autonomy, contribute to students' motivation for learning, or enhance class discussions (Items 2, 4, and 14, $M=3.14$ ). They did not provide a clear answer concerning whether students could be approached easily using online platforms (Item 10, M =3.05) or whether responding to student inquiries took time (Item 11, M = 2.91). In general, the instructors were neutral on the issue of whether online learning contributed to students' overall learning achievements (Item 5, M = 2.77). Moreover, the instructors were not in favor of having more translation subjects taught online (Item 15, M = 2.5), and despite the perceived benefits of ODL, they preferred the traditional face-to-face teaching of translation subjects compared to the online method (Item $3, \mathrm{M}=2.23)$.

\section{Students' Perceptions of Online Distance Learning}

The second question concerned students' perceptions of using eLearning platforms for translation subjects. Table 3 presents the means and standard deviations of each item according to the students' responses.

Table 3. Means and standard deviations of the student questionnaire items

\begin{tabular}{cclcc}
$\begin{array}{c}\text { Item } \\
\text { No. }\end{array}$ & Rank & Item & Mean & $\begin{array}{c}\text { Standard } \\
\text { Deviation }\end{array}$ \\
\hline 2 & 1 & ODL enhances students' learning autonomy (i.e., self-learning). & 3.67 & 0.97 \\
\hline 8 & 2 & $\begin{array}{l}\text { The methods of presentation and content delivery are } \\
\text { appropriate for learning. }\end{array}$ & 3.5 & 0.99 \\
\hline 6 & 3 & $\begin{array}{l}\text { The tasks and assignments given can be understood easily and } \\
\text { facilitate learning. }\end{array}$ & 3.47 & 1.07 \\
\hline 5 & 4 & ODL contributes to students' learning achievements. & 3.44 & 0.99 \\
\hline 11 & 5 & Responding to student inquiries takes time. & 3.43 & 1.05 \\
\hline 1 & 6 & ODL is useful for translation courses. & 3.38 & 1.28 \\
\hline 13 & 7 & $\begin{array}{l}\text { There is a lack of social interaction between the instructor and } \\
\text { students, and among the students themselves. }\end{array}$ & 3.33 & 1.12 \\
\hline 12 & 8 & $\begin{array}{l}\text { There are opportunities for collaborative work in ODL (i.e., } \\
\text { completing tasks/assignments in cooperation with classmates). }\end{array}$ & 3.31 & 1.23 \\
\hline 9 & 9 & $\begin{array}{l}\text { It is easy for students to understand the course contents when } \\
\text { studying online. }\end{array}$ & 3.25 & 1.23 \\
\hline 15 & 10 & I would like to have more translation courses taught online. & 3.19 & 1.42 \\
\hline 7 & 11 & $\begin{array}{l}\text { Feedback on assignments and examinations is timely (i.e., } \\
\text { feedback is sent back to students quickly). }\end{array}$ & 3.17 & 1.27 \\
\hline
\end{tabular}




\begin{tabular}{cclcc}
\hline 4 & 12 & $\begin{array}{l}\text { ODL does not increase students' motivation for learning. } \\
\text { (negative statement) }\end{array}$ & 3.12 & 1.18 \\
\hline 10 & 13 & $\begin{array}{l}\text { Course instructors cannot be contacted easily. (negative } \\
\text { statement) }\end{array}$ & 3.02 & 1.14 \\
\hline 3 & 14 & $\begin{array}{l}\text { I prefer ODL translation courses to the traditional ones (i.e., face- } \\
\text { to-face teaching). }\end{array}$ & 2.96 & 1.42 \\
\hline 14 & 15 & $\begin{array}{l}\text { It is difficult to contribute to class discussions in an ODL } \\
\text { translation course. }\end{array}$ & 2.93 & 1.22 \\
\hline & Overall mean & 3.28 & 0.435 \\
\hline
\end{tabular}

As shown in Table 3, the overall mean score of the students' perceptions of using online classes for translation subjects was neutral $(M=3.28)$. The means generally ranged from 2.93 to 3.67 , with standard deviations from 0.97 to 1.42 . Items $2,8,6,5$, and 11 had mean scores of 3.43 to 3.67. These items fell within the "agree" category, which roughly constituted $27 \%$ of the total number of items. Then, Items $1,13,12,9,15$, $7,4,10,3$, and 14 had mean scores ranging from 2.93 to 3.38, which fell within the "neutral" category that constituted $73 \%$ of all items.

These findings showed that the students agreed online learning enhanced their learning autonomy (Item 2, $M=3.67)$. Further, similar to the instructors, the students believed the online methods of presentation and content delivery were appropriate for learning (Item 8, M =3.5). There was a student consensus that the tasks and assignments could be easily understood, which helped facilitate their learning (Item 6, M = 3.47), and the students believed this contributed to their overall learning achievements (Item 5, M =3.44).

The students reported that the instructors did not provide prompt responses to their inquiries (Item 11, M $=3.43$ ). They were undecided about the overall usefulness of online learning for translation subjects (Item $1, \mathrm{M}=3.38$ ) as well as about whether there were opportunities for social interactions (Item 13, $\mathrm{M}=3.33$ ) or collaborative work on tasks and assignments (Item 12, M =3.31). For the remaining items (Items 9, 15, 7, 4, 10, and 3), they indicated neutral perceptions. Unlike the instructors, for example, the students were uncertain about whether they would like to have more translation courses taught online (Item 15, M = 3.19) and whether they preferred online learning to the traditional face-to-face method (Item 3, M = 2.96).

\section{Instructors' and Students' Perceptions of Online Distance Learning}

An independent samples t-test was performed to compare the instructors' and students' responses. Table 4 presents the results.

Table 4. Independent samples t-test to compare instructor and student responses

\begin{tabular}{|c|c|c|c|c|c|c|}
\hline Dimension & Participant & $\mathrm{n}$ & Mean & SD & $\mathrm{t}$ & Sig \\
\hline \multirow{2}{*}{$\begin{array}{l}\text { Perception of using Online } \\
\text { Distance eLearning (ODL) for } \\
\text { translation courses }\end{array}$} & instructor & 22 & 3.18 & 0.233 & -1.537 & 0.131 \\
\hline & student & 133 & 3.28 & 0.435 & & \\
\hline
\end{tabular}

As can be seen from Table 4, there were no statistically significant differences between the instructors' responses $(\mathrm{M}=3.18, \mathrm{SD}=0.23)$ and students' responses $(\mathrm{M}=3.28, \mathrm{SD}=0.43)$ at the significance level of $\mathrm{p}<0.05$. This suggests the two groups had similar perceptions of the use of online learning for translation courses.

\section{DISCUSSIONS AND CONCLUSION}

This study explored instructors' and students' perceptions of using online platforms for teaching and learning translation subjects. Quantitative data were collected from a sample of 22 faculty members and 133 undergraduate students in the DELT at KSU. 
Concerning the first research question about instructors' perceptions, the findings showed that, despite an overall neutral stance, instructors reported several benefits. They reported general agreement that eLearning was useful for appropriate delivery of course content, which might enable students to understand assignments more easily and facilitate their learning. This finding is consistent with those of Al-Ammary et al. (2014) and Alwahoub et al. (2020), who concluded that eLearning gave students easier access to materials and contributed to their learning. Another finding of this study was the instructors' belief that eLearning provided opportunities for collaborative work, in agreement with previous studies. Banafshi et al. (2020), for example, reported that students receiving eLearning instruction interacted more and engaged in more collaborative patterns. Alruwais et al. (2018) also noted more interaction in eLearning than conventional learning. This finding is unsurprising given that eLearning can provide more opportunities to practice and communicate beyond the limited time of an onsite classroom (Ortega, 2007). In computer-mediated L2 learning, learners have additional time to contribute to a task, thereby reducing pressure, particularly on shy students, and encouraging everyone to participate (Meyer, 2003).

However, the present study could not confirm the findings of Alfehaid (2019), who reported university instructors' belief in a positive impact of eLearning on overall academic achievement. This may be attributed to a number of factors. For example, learning in Saudi Arabia has shifted abruptly to an online mode due to the COVID-19 pandemic. Particularly for translation subjects, which were not previously provided online in the DELT, the experience may have rendered instructors unable to notice the effects of eLearning on student achievement. For instance, translation subjects are normally delivered face-to-face, where specialized laboratories and interpretating tools are used to solve translation tasks, promote written and verbal skills, and provide immediate constructive feedback. The absence of these essential resources as well as the technical issues that arose in the first few weeks following university closures could have restricted instructors and students' practices, leaving little-to-no chance for instructors to capture the actual effect of such experience on overall achievement. Moreover, these factors can explain why instructors in this study were unwilling to teach translation courses online, preferring face-to-face instruction. This finding is consistent with previous studies. For example, Alwahoob et al. (2020) concluded that although teachers found eLearning to be useful, they still regarded face-to-face interaction as important because it helped students strengthen their communication and other skills. In addition, Al-Hattami (2020) reported that teachers were willing to use eLearning in the future.

Next, concerning the second research question about students' perceptions, the study findings indicate general agreement among the students that ODL enhanced their learning autonomy. This is consistent with Cabi and Kalelioglu's (2019) finding that ODL improved students' self-directed learning skills. In this study, the students who used ODL platforms, either synchronously or asynchronously, were likely to have more opportunities to become more active participants with additional responsibilities that could ultimately have contributed to their overall learning autonomy. An important point reported by students in this study was that they understood assignments more easily and eLearning facilitated their learning. This result, in agreement with Aljuda (2017), may be attributed to ODL's flexibility. In translation subjects, students need time to read, look up words, and analyze texts carefully_-tasks that normally have far more limited time in classrooms. Therefore, the accessibility of assignments, regardless of time and location, may have provided greater opportunities for conscious attention, through which students could analyze texts, notice errors, and solve text-related issues. Such processes can bring about better learning outcomes (Storch, 2013).

Despite some of the reported benefits, the results showed generally neutral perceptions from instructors and students. Therefore, instructors and students might have a preconceived awareness of several but not all benefits of eLearning. For this reason, the study recommends increasing this awareness through workshops on using eLearning platforms for translation, online help, and regular support. Extensive and consistent training would help instructors and students become more comfortable with this mode of learning. Similarly, Fathema and Sutton (2013) suggested users would like universities to offer extensive training programs. Furthermore, policymakers should expand the use of eLearning platforms to include particular types of instructional materials and tools. For example, university authorities could integrate translation software into their eLearning platforms to make these tools accessible off campus. Technical developers should also provide support to instructors and students to ensure effective and continuous implementation. Failure to provide more learning resources and technical support could lead to minimal use of eLearning. 
Although the findings may add some insights to the field of teaching and learning translation subjects, this study has a number of limitations. The data were all from one university in Saudi Arabia, i.e., KSU. In order to make a valid claim, a larger scale study across different universities would be required to make the results generalizable to a larger context. Future research should also consider the impact of gender on participants' perceptions. Another limitation is that this study is merely quantitative. Thus, future studies should consider post-treatment interviews with both the instructors and students in order to investigate this topic more comprehensively. In conclusion, the results of the present study add to the body of studies on the perceptions of instructors and students regarding ODL in an EFL context.

Acknowledgements: The author expresses his appreciation to the Deanship of Scientific Research and RSSU at King Saud University, Saudi Arabia, and the Research Center at the College of Languages \& Translation for offering support for this article.

\section{BIODATA and CONTACT ADDRESSES of AUTHOR}

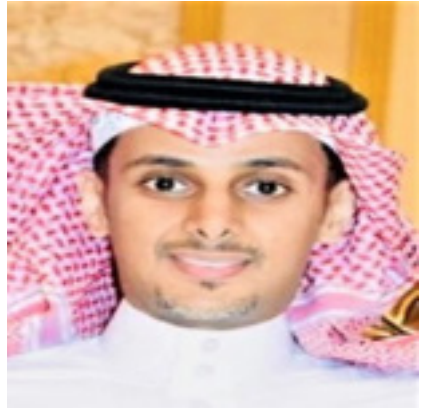

Dr. Khaled ALDOSSARY is an Assistant Professor of Applied Linguistics in the Department of English Language and Translation, King Saud University, Riyadh, Saudi Arabia. Dr. Khaled gained his Ph.D. in Applied Linguistics and Educational Linguistics at September, 2017 from the University of Melbourne. His academic interest areas are ESL/EFL academic writing, feedback on writing, collaborative learning, and computer-mediated language learning.

\section{Dr. Khaled ALDOSSARY}

Department of English Language and Translation

College of Languages and Translation

Address: King Saud University, 11652, Riyadh, Saudi Arabia

Phone: +966566595868

E-mail: kdossary@ksu.edu.sa

\section{REFERENCES}

Al-Ammary, J. H., Al-Sherooqi, A. K., \& Al-Sherooqi, H. K. (2014). The acceptance of social networking as a learning tools at University of Bahrain. International Journal of Information and Education Technology, 4(2), 208.

Alfehaid, A. (2019). Online English language learning activities and academic achievement: experiences of first year students and their teachers. Pertanika Journal of Social Sciences \& Humanities, $27(2)$.

Al-Hattami, A. A. (2020). E-assessment of students' performance during the e-teaching and learning. International Journal of Advanced Science and Technology, 29(8s), 1537-1547.

Aljaber, A. (2018). E-learning policy in Saudi Arabia: Challenges and successes. Research in Comparative and International Education, 13(1), 176-194.

Al-Juda, M. Q. B. (2017). Distance learning students' evaluation of e-learning system in university of Tabuk, Saudi Arabia. Journal of Education and Learning, 6(4), 324-335.

Alodail, A. (2016). The instructors' attitudes toward the use of E-Learning in classroom in College of Education at Albaha University. Turkish Online Journal of Educational Technology-TOJET, 15(1), 126-135. 
Alruwais, N., Wills, G., \& Wald, M. (2018). Advantages and challenges of using e-assessment. International Journal of Information and Education Technology, 8(1), 34-37.

Alwahoub, H. M., Azmi, M. N. L., \& Jomaa, N. J. (2020). Teachers' and students' perceptions of e-learning integration in the primary schools of Saudi Arabia. International Journal of Advanced Research in Education and Society, 2(1), 116-126.

Alzahrani, M. G. (2017). The developments of ICT and the need for blended learning in Saudi Arabia. Journal of Education and Practice, 8(9), 79-87.

Anas, A. (2020). Perceptions of Saudi students to blended learning environments at the university of Bisha, Saudi Arabia. Arab World English Journal (AWEJ) Special Issue on CALL (6). 261-277.

Banafshi, M., Khodabandeh, F., \& Hemmati, F. (2020) Comparing EFL learners' responses in online and traditional classes: a mixed method approach. Turkish Online Journal of Distance Education, 21(4), 124-142.

Bonwell, C. C., \& Eison, J. A. (1991). Active learning: creating excitement in the classroom. New York: ERIC Clearinghouse on Higher Education.

Cabi, E., \& Kalelioglu, F. (2019). A fully online course experience from students' perspective: readiness, attitudes and thoughts. Turkish Online Journal of Distance Education, 20(3), 165-180.

Fathema, N., \& Sutton, K. L. (2013). Factors influencing faculty members' learning management systems adoption behavior: an analysis using the technology acceptance model. International Journal of Trends in Economics Management \& Technology (IJTEMT), 2(6).

Geta, M., \& Olango, M. (2016). The impact of blended learning in developing students' writing skills: Hawassa University in focus. African Educational Research Journal, 4(2), 49-68.

Getie, A. S. (2020). Factors affecting the attitudes of students towards learning English as a foreign language. Cogent Education, 7(1), 1738184.

Gülbahar, Y. (2012). Study of developing scales for assessment of the levels of readiness and satisfaction of participants in e-learning environments. Journal of Faculty of Educational Sciences, 45(2).

Hew, K. F., Qiao, C., \& Tang, Y. (2018). Understanding student engagement in large-scale open online courses: A machine learning facilitated analysis of student's reflections in 18 highly rated MOOCs. International Review of Research in Open and Distributed Learning, 19(3).

Hockly, N. (2015). Developments in online language learning. ELT Journal, 69(3), 308-313.

Isti'anah, A. (2017). The effect of blended learning to the students' achievement in grammar class. IJEE (Indonesian Journal of English Education), 4(1), 16-30.

Junior, F., Botelho, E., Rego, M., Faiad, C., \& Ramos, W. (2019). Attitudes towards online learning: what do Brazilian students think about? Turkish Online Journal of Distance Education, 20(4), 117-134.

Keengwe, J. (2015). Handbook of research on educational technology integration and active learning. USA: IGI Global.

Kishore, N. P., \& Alekhya, N. (2018). An introduction to active learning strategies. New Delhi: Educreation Publishing.

Meyer, K.A. (2003) Face-to-face versus threaded discussions: the role of time and higher order thinking. Journal of Asynchronous Learning Networks, 7(3), 55-65.

Nazara, S. (2019). The flipped classroom use in EFL learning and teaching. Paper presented at The UKI English Education Department Bimonthly Collegiate Forum. Jakarta, Indonesia.

Northcote, M., \& Gosselin, K. P. (2016). Handbook of research on humanizing the distance learning experience. USA: IGI Global.

Ortega, L. (2007) Meaningful L2 practice in foreign language classrooms: A cognitiveinteractionist SLA perspective. In R.M. DeKeyser (ed.) Practice in a second language. Perspectives from applied linguistics and cognitive psychology (pp. 180-207). Cambridge: Cambridge University Press. 
Rhema, A., \& Miliszewska, I. (2014). Analysis of student attitudes towards e-learning: The case of engineering students in Libya. Issues in Informing Science and Information Technology, 11(1), 169-190.

Rice, S., \& Gregor, M. N. (2016). E-Learning and the academic library: Essays on innovative initiatives. USA: Macfarland \& Company, Inc.

Sajid, M. R., Laheji, A. F., Abothenain, F., Salam, Y., AlJayar, D., \& Obeidat, A. (2016). Can blended learning and the flipped classroom improve student learning and satisfaction in Saudi Arabia? International Journal of Medical Education, 7, 281.

Sanad, H. (2020). Perceptions towards E-learning in times of COVID-19 lockdown phase in the tertiary education. Journal of Research in Curriculum Instruction and Educational Technology, 6(4), 77121.

Storch, N. (2013). Collaborative writing in L2 classrooms. Bristol: Multilingual Matters.

Suwantarathip, O., \& Wichadee, S. (2014). The effects of collaborative writing activity using Google Docs on students' writing abilities. Turkish Online Journal of Educational Technology-TOJET, 13(2), 148-156.

Tan, L., Wigglesworth, G., \& Storch N. (2010). Pair interactions and mode of communication: comparing face-to-face and computer mediated communication. Australian Review of Applied Linguistics 33(3), 1-24.

Tunmibi, S., Aregbesola, A., Adejobi, P., \& Ibrahim, O. (2015). Impact of e-learning and digitalization in primary and secondary schools. Journal of Education and Practice, 6(17), 53-58.

Zabadi, A. M., \& Al-Alawi, A. H. (2016). University students' attitudes towards e-learning: University of Business \& Technology (UBT) -Saudi Arabia- Jeddah: A case study. International Journal of Business and Management, 11(6), 286-295. 


\section{APPENDIX A}

\section{The Instructors' Questionnaire}

The following questionnaire aims to elicit your perceptions of the recent experience of using Online Distance e-Learning (ODL) for teaching English translation subjects in the College of Languages and Translation (COLT), King Saud University (KSU). Please ensure that the information provided is accurate. All information collected will be highly confidential and will only be used for the purpose of this study. Your participation is very much appreciated.

\section{Instructors' Questionnaire}

\begin{tabular}{|c|c|c|c|c|c|c|}
\hline \multicolumn{7}{|c|}{ Perceptions of using Online Distance e-Learning (ODL) to teach translation courses. } \\
\hline No & Item & $\begin{array}{l}\text { Strongly } \\
\text { Agree } \\
1\end{array}$ & $\begin{array}{c}\text { Agree } \\
2\end{array}$ & $\begin{array}{c}\text { Undecided } \\
3\end{array}$ & $\begin{array}{c}\text { Disagree } \\
4\end{array}$ & $\begin{array}{c}\text { Strongly } \\
\text { Disagree } \\
5\end{array}$ \\
\hline 1 & ODL is useful for translation courses. & o & o & o & o & o \\
\hline 2 & $\begin{array}{l}\text { ODL enhances students' learning } \\
\text { autonomy (i.e., self-learning). }\end{array}$ & o & o & o & o & o \\
\hline 3 & $\begin{array}{l}\text { I prefer ODL translation courses to } \\
\text { the traditional ones (i.e., face-to-face } \\
\text { teaching). }\end{array}$ & o & 0 & o & 0 & o \\
\hline 4 & $\begin{array}{l}\text { ODL does not increase students' } \\
\text { motivation for learning. (negative } \\
\text { statement) }\end{array}$ & 0 & 0 & o & o & o \\
\hline 5 & $\begin{array}{l}\text { ODL contributes to students' learning } \\
\text { achievements. }\end{array}$ & o & o & o & o & o \\
\hline 6 & $\begin{array}{l}\text { The tasks and assignments are easily } \\
\text { understood and facilitate learning. }\end{array}$ & o & o & o & o & o \\
\hline 7 & $\begin{array}{l}\text { Feedback on assignments and } \\
\text { examinations is timely (i.e., feedback is } \\
\text { sent back to students quickly). }\end{array}$ & 0 & 0 & o & 0 & o \\
\hline 8 & $\begin{array}{l}\text { The methods of presentation and } \\
\text { content delivery are appropriate for } \\
\text { learning. }\end{array}$ & o & 0 & o & o & o \\
\hline 9 & $\begin{array}{l}\text { It is easy for students to understand } \\
\text { the content when studying online. }\end{array}$ & o & o & o & o & o \\
\hline 10 & $\begin{array}{l}\text { Students cannot be contacted easily. } \\
\text { (negative statement) }\end{array}$ & o & 0 & 0 & 0 & 0 \\
\hline 11 & $\begin{array}{l}\text { Responding to students' inquiries } \\
\text { takes time. }\end{array}$ & 0 & 0 & 0 & 0 & 0 \\
\hline 12 & $\begin{array}{l}\text { There are opportunities for } \\
\text { collaborative work in ODL (i.e., } \\
\text { completing tasks/assignments in } \\
\text { cooperation with classmates). }\end{array}$ & 0 & 0 & 0 & 0 & 0 \\
\hline 13 & $\begin{array}{l}\text { There is a lack of social interaction } \\
\text { between the instructor and students, } \\
\text { and among the students themselves. }\end{array}$ & 0 & 0 & 0 & 0 & 0 \\
\hline 14 & $\begin{array}{l}\text { It is difficult to contribute to class } \\
\text { discussions in an ODL translation } \\
\text { course. }\end{array}$ & 0 & 0 & 0 & 0 & 0 \\
\hline 15 & $\begin{array}{l}\text { I would like to have more translation } \\
\text { courses taught online. }\end{array}$ & 0 & 0 & 0 & 0 & 0 \\
\hline
\end{tabular}




\section{APPENDIX B}

\section{The Students' Questionnaire}

The following questionnaire aims to elicit your perceptions of the recent experience of using Online Distance e-Learning (ODeL) for studying English translation subjects at the College of Languages and Translation (COLT). Please ensure that the information provided is accurate to help achieve the best outcomes for this study. All information collected will be highly confidential and will only be used for the purpose of this study. Your participation is very much appreciated.

\section{Students' Questionnaire}

\begin{tabular}{|c|c|c|c|c|c|c|}
\hline \multicolumn{7}{|c|}{ Perceptions of using Online Distance e-Learning (ODeL) to study translation courses. } \\
\hline No & Item & $\begin{array}{l}\text { Strongly } \\
\text { Agree } \\
1\end{array}$ & $\begin{array}{l}\text { Agree } \\
2\end{array}$ & $\begin{array}{l}\text { Undecided } \\
\qquad 3\end{array}$ & $\begin{array}{c}\text { Disagree } \\
4\end{array}$ & $\begin{array}{c}\text { Strongly } \\
\text { Disagree } \\
5\end{array}$ \\
\hline 1 & ODL is useful for translation courses. & o & o & 0 & o & O \\
\hline 2 & $\begin{array}{l}\text { ODL enhances students' learning } \\
\text { autonomy (i.e., self-learning). }\end{array}$ & o & o & 0 & o & 0 \\
\hline 3 & $\begin{array}{l}\text { I prefer ODL translation courses to } \\
\text { the traditional ones (i.e., face-to-face } \\
\text { teaching). }\end{array}$ & o & o & 0 & 0 & o \\
\hline 4 & $\begin{array}{l}\text { ODL does not increase students' } \\
\text { motivation for learning. (negative } \\
\text { statement). }\end{array}$ & o & o & 0 & o & 0 \\
\hline 5 & $\begin{array}{l}\text { ODL contributes to students' learning } \\
\text { achievements. }\end{array}$ & 0 & 0 & 0 & 0 & 0 \\
\hline 6 & $\begin{array}{l}\text { The tasks and assignments given can } \\
\text { be understood easily and facilitate } \\
\text { learning. }\end{array}$ & 0 & 0 & 0 & 0 & 0 \\
\hline 7 & $\begin{array}{l}\text { Feedback on assignments and } \\
\text { examinations is timely (i.e., feedback is } \\
\text { sent back to students quickly). }\end{array}$ & 0 & 0 & 0 & 0 & 0 \\
\hline 8 & $\begin{array}{l}\text { The methods of presentation and } \\
\text { content delivery are appropriate for } \\
\text { learning. }\end{array}$ & 0 & 0 & 0 & 0 & 0 \\
\hline 9 & $\begin{array}{l}\text { It is easy for students to understand the } \\
\text { course contents when studying online. }\end{array}$ & 0 & 0 & 0 & 0 & 0 \\
\hline 10 & $\begin{array}{l}\text { Course instructors cannot be contacted } \\
\text { easily. (negative statement). }\end{array}$ & 0 & 0 & 0 & 0 & 0 \\
\hline 11 & $\begin{array}{l}\text { Responding to students' inquiries takes } \\
\text { time. }\end{array}$ & 0 & 0 & 0 & 0 & 0 \\
\hline 12 & $\begin{array}{l}\text { There are opportunities for } \\
\text { collaborative work in ODL (i.e., } \\
\text { completing tasks/assignments in } \\
\text { cooperation with classmates). }\end{array}$ & 0 & 0 & 0 & 0 & 0 \\
\hline 13 & $\begin{array}{l}\text { There is a lack of social interaction } \\
\text { between the instructor and students, } \\
\text { and among the students themselves. }\end{array}$ & 0 & 0 & 0 & 0 & 0 \\
\hline 14 & $\begin{array}{l}\text { It is difficult to contribute to class } \\
\text { discussions in an ODL translation } \\
\text { course. }\end{array}$ & 0 & 0 & 0 & 0 & 0 \\
\hline 15 & $\begin{array}{l}\text { I would like to have more translation } \\
\text { courses taught online. }\end{array}$ & 0 & 0 & 0 & 0 & 0 \\
\hline
\end{tabular}

